\title{
ABSTRAK \\ PEMANFAATAN LIMBAH KULIT PISANG SEBAGAI BAHAN OLAHAN KRIPIK DAN KUE DONAT DI DESA BATU MERAH KOTA AMBON
}

\author{
${ }^{1}$ D. Wakano, ${ }^{2}$ E. Samson, dan ${ }^{3}$ L. D. Tetelepta \\ 1,2,3 Jurusan Biologi Fakultas Matematika dan Ilmu Pengetahuan Alam \\ E-mail: ${ }^{1}$ delly_wakano@yahoo.co.id, ${ }^{2}$ givenefse@yahoo.com, \\ ${ }^{3}$ dy_tetelepta4christ@yahoo.com
}

\begin{abstract}
Abstarak: Kulit pisang memiliki kandungan air 68,9 g, KH 18,5 g, Protein 0,32 g, Lemak $2,11 \mathrm{~g}$, kalsium $715 \mathrm{mg}$, Fosfor $117 \mathrm{mg}$, besi 1,6 mg, vitamin B 0,12 mg, dan vitamin C 17,5 mg Berdasarkan uraian tentang nilai gizi limbah kulit pisang tersebut diatas, maka perlu dilakukan pengolahan limbah kulit pisang sebagai sumber makanan seperti kripik dan kue donat. Tipe penelitian yang digunakan dalam penelitian ini adalah deskriptif kualitatif. Hasil adalah Pengetahuan masyarakat desa Batu Merah meningkat tentang pengolahan limbah kulit pisang menjadi kripik dan kue. Pencemaran lingkungan akibat limbah kulit pisang yang dibuang ke sembangan tempat telah diminimalisir dengan diolahnya menjadi kripik dan kue. Masyarakat Desa Batu Merah telah memanfaatkan limbah kulit pisang sebagai sumber makanan yang berkalsium tinggi guna memenuhi kebutuhan gizi keluarga dan telah dimanfaatkan oleh masyarakat untuk memenuhi kebutuhan hidup. Sedangkan nilai gizinya setelah pengolahan lebih tinggi yaitu Zat gizi untuk Kripik karbihidrat 42,5 \%, Protein 1,00 \%, Lemak 1,5\%, Kalsium 7,5 \%, Fosfor 9,5\%, Besi 1,2 \%. Vitamin B 0,9 \%Vitamin C 1,75\%. Sedangkan untuk donat karbohidrat $52,9 \%$, protein $1,32 \%$, lemak 2,3\%, kalsium $10 \%$, fosfor $11,5 \%$, Besi $2.1 \%$, Vtamin B1 $5 \%$,dan vitamin C $2.59 \%$.
\end{abstract}

\section{Kata Kunci: Kulit Pisang, Kue Donat, dan Kripik Kulit Pisang}

Kota Ambon merupakan ibu kota dari provinsi Maluku. Kota ini dikenal juga dengan nama "Ambon Manise" yang berarti kota Ambon yang indah/manis/cantik, dan merupakan Kota terbesar di wilayah kepulauan Maluku dan menjadi sentral bagi wilayah kepulauan Maluku. Saat ini kota Ambon menjadi pusat pelabuhan, perdagangan, pariwisata dan pendidikan. Salah satu desa yang merupakan pusat perdagangan dan pemukiman penduduk yang besar dan menduduki peringkat pertama di Maluku adalah desa Batu Merah (Anonim, 2015)

Desa Batu Merah merupakan desa di kecamatan Sirimau yang terbagi atas 2 wilayah yaitu Batu Merah Atas dan Batu Merah Bawah. Secara umum, kepadatan penduduk di desa ini sangatlah tinggi dengan variasi suku dan profesi. Salah satu profesi 
yang cukup banyak diguluti adalah pedagang pisang. Pisang (Musaceaea sp) merupakan tanaman penghasil buah yang banyak terdapat di Maluku khususnya kota Ambon. Buahnya banyak disukai untuk dikonsumsi secara langsung sebagai buah atau diolah menjadi produk konsumsi lain seperti digoreng, direbus, dibakar, atau dikolak. Selain itu juga buah pisang dapat diolah menjadi Pisang Molen, sale pisang, kripik pisang, selai pisang, dan lain sebagainya.

Namun hal ini tidak diimbangi dengan pengolahan limbah dari kulit pisang yang sangat banyak jumlahnya tersebut. Pada umumnya kulit pisang belum dimanfaatkan secara nyata, hanya dibuang sebagai limbah organik saja atau digunakan sebagai makanan ternak seperti kambing, sapi, dan kerbau. Jumlah kulit pisang yang cukup banyak akan memiliki nilai jual yang menguntungkan apabila bisa dimanfaatkan sebagai bahan baku makanan. Penelitian terdahulu menunjukkan bahwa Limbah kulit pisang mengandung zat gizi yang cukup tinggi terutama vitamin dan mineralnya sehingga dapat dimanfaatkan sebagai bahan baku makanan. Kulit pisang memiliki kandungan air 68,9 g, KH 18,5 g, Protein 0,32 g, Lemak 2,11 g, kalsium $715 \mathrm{mg}$, Fosfor $117 \mathrm{mg}$, besi 1,6 mg, vitamin B 0,12 mg, dan vitamin C 17,5 mg (Balai Penelitian dan Pengembangan Industri, Suprapti 2005).

Berdasarkan uraian tentang nilai gizi limbah kulit pisang tersebut di atas, maka perlu dilakukan pengolahan limbah kulit pisang sebagai sumber makanan seperti kripik dan kue donat, sehingga dapat meminimalisir pencemaran lingkungan akibat sampah dan sebagai alternatif produk pangan ramah lingkungan dan dapat bernilai tambah dalam menunjang perekonomian masyarakat, dari segi pendapatan dan mengurangi biaya kebutuhan rumah tangga.

\section{METODE PENELITIAN}

Tipe penelitian yang digunakan dalam penelitian ini adalah deskriptif kualitatis guna mengambarkan pola pemanfaatan limbah kulit pisang sebagai bahan olahan kripik dan kue donat di desa Batu Merah Kota Ambon. Penelitian ini dilakukan di Desa Batu Merah Kota Ambon, dengan waktu penelitian yaitu mulai dari bulan April-September 2016. 
Pengelolahan limbah kulit pisang sebagai kripik adalah pertama kulit pisang diambil dan dicuci hingga bersih, kemudian buat larutan kapur, setelah itu, rendam kulit pisang dalam larutan air kapur sirih, kemudian buat larutan garam, kemudian rendam kulit pisang dalam larutan garam, kemudian buat larutan gula, rendam kulit pisang dalam larutan gula, jemur kulit pisang hingga kering, Goreng kulit pisang kering hingga kuning kecoklatan, Jika menginginkan penggorengan dengan tepung, maka masukkan kulit pisang dalam adonan tepung, setelah terlihat keripik pisang mulai berwarna kuning, angkat dari penggorengan dan tiriskan, kemudian sajikan keripik kulit pisang tersebut.

Sedangkan pengelolaan limbah kulit pisang sebagai kue adalah pertama bersihkan kulit pisang dan dicuci hingga bersih, kemudian kulit pisang tersebut direbus hingga agak lembek, setelah itu diblender kulit pisang hingga hancur, kemudian dicampurkan tepung terigu dan kulit pisang yang sudah di hancurkan dengan perbandingan tepung terigu : kulit pisang (1:2), Ditambahkan gula, margarin, kuning telur dan ragi pengembang kue sambil diuleni hingga kalis dan menjadi adonan, Diamkan adonan selama 20 menit dengan ditutupi oleh kain, Bagi adonan dengan merata, adonan yang sudah siap lalu digoreng dengan api kecil hingga warnanya agak kecoklatan, didinginkan dahulu, kemudian kue siap untuk disaji.

\section{HASIL PENELITIAN}

\section{Pendekatan Awal Kepada Masyarakat Desa Batu Merah}

Pada pendekatan awal ini tiem pelaksana melakukan pendekatan dengan staf pemerintah desa dan para pedagang pisang dan kepala sekolah di Desa Batu Merah guna menyampaikan maksud dari kegiatan. (Gambar 1)

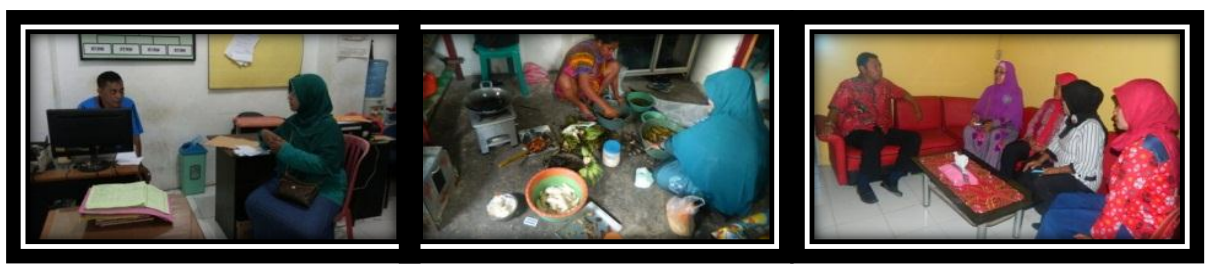

Gambar 1. a. Pendekaan awal dengan bapak Raja Negeri Batu Merah, b. Penjual Pisang, dan c. Pendekatan dengan salah satu kepala sekolah Negeri batu Merah

Dari observasi yang dilakukan maka mendapat respon yang positif dari pemerintah desa, pedagang pisang dan salah satu pihak sekolah. 


\section{Proses Pembuatan Kripikdan Kue Donat}

Adapun proses pembuatan kripik dan kue donat dapat dilihat pada Gambar 2 berikut ini:

a. Proses pembuatan Kripik (Gambar 2)
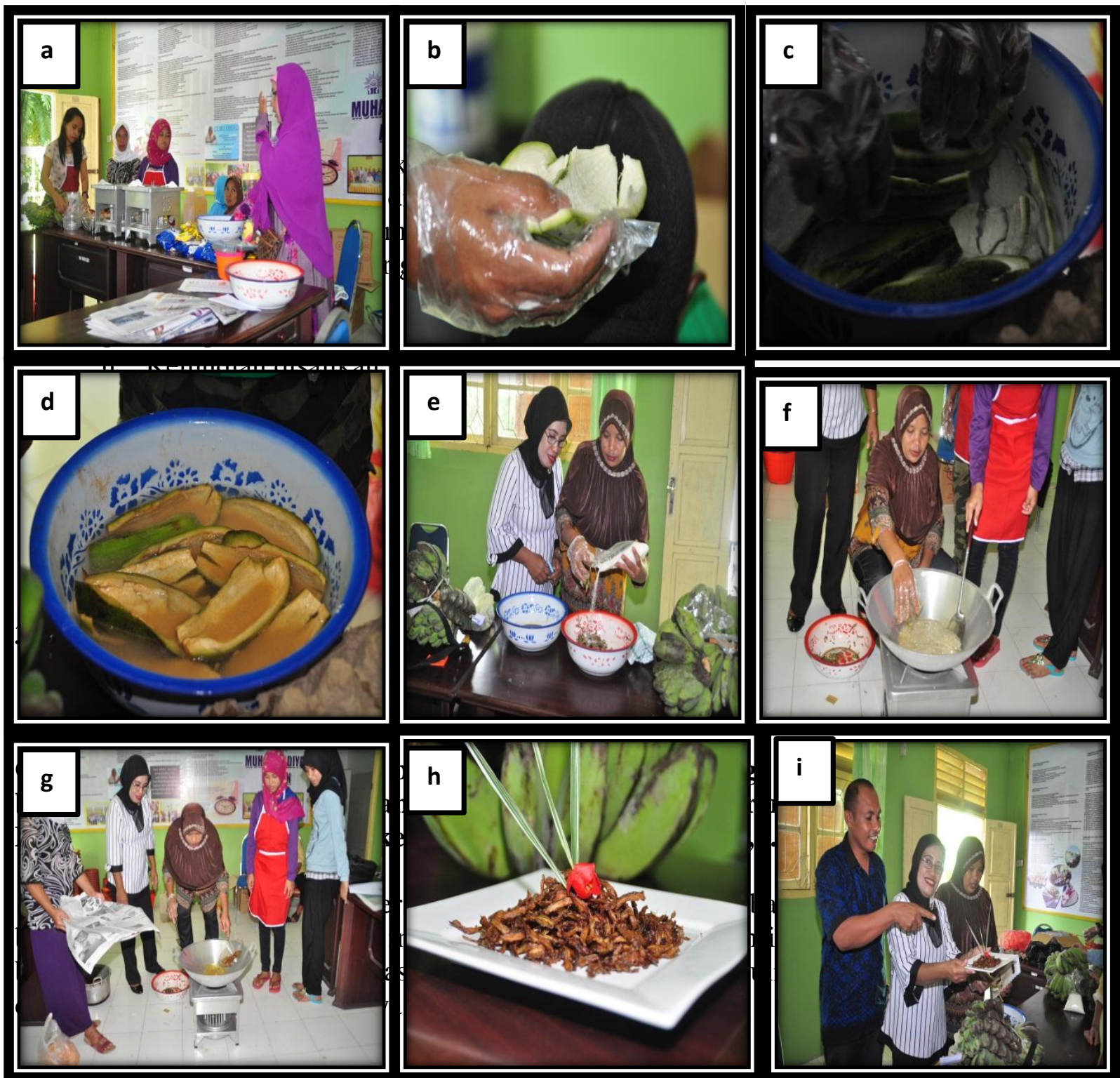

BIOLOGI SEL (VOL 5 NO 2 EDISI JUL-DES 2016 ISSN 2252-858X/E-ISSN 2541-1225) PAGE 155 


\section{b.Proses Pembuatan Kue Donat (Gambar 3)}
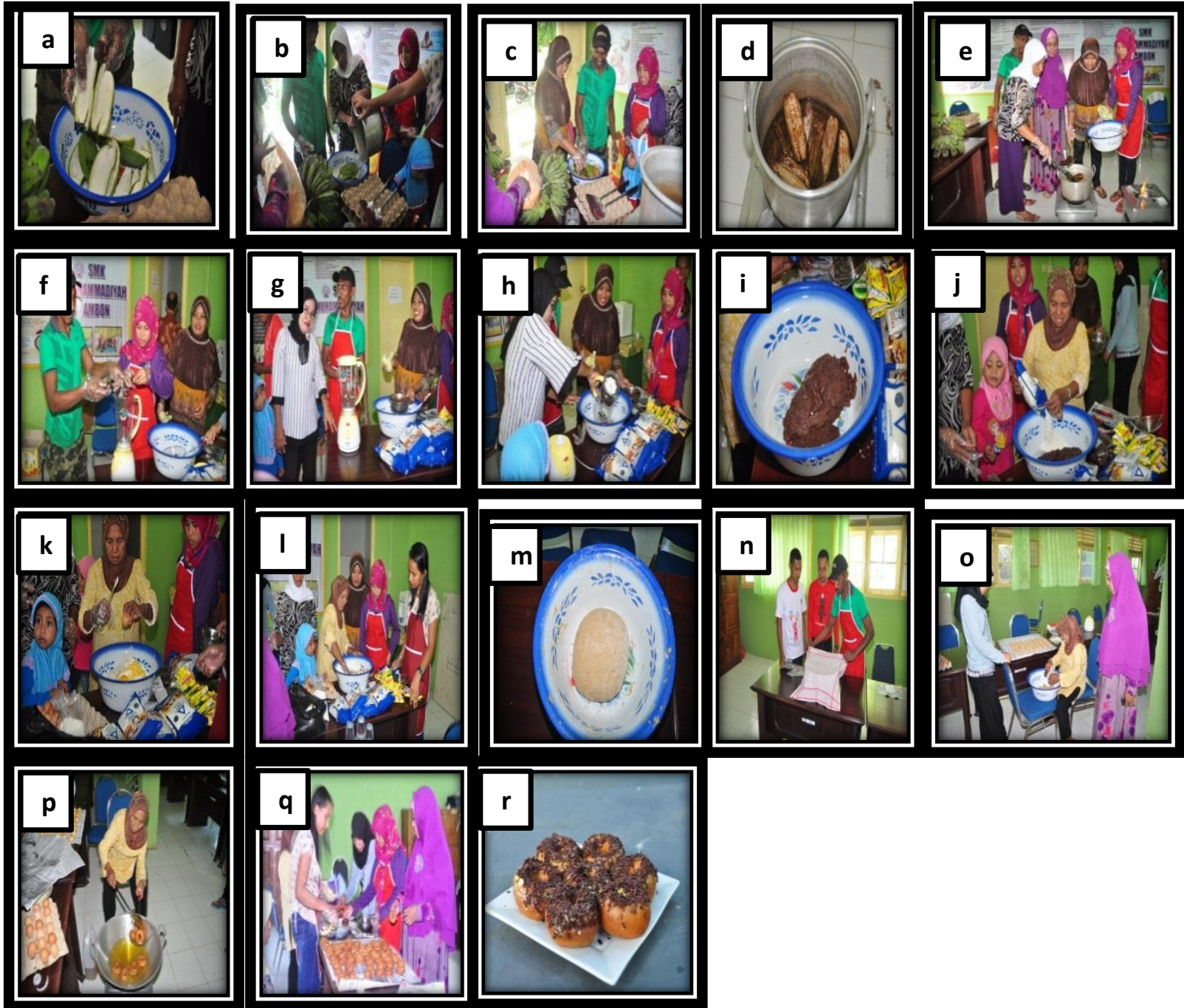

Gambar 3. a. Pengambilan limbah kulit Pisang, b. Dicuci bersih, c. Direndam dengan air kapur, d. Direbus hingga lembek, e. Diangkat kemudian ditiriskan, f. Diiris kecil-kecil, g. Dibender hingga halus, h. Dituangkan kedalam wadah, i. Hasil blender kulit pisang, j. Kemudian tambahkan tepung terigu, k. Margarin, telur, susu bubuk, ragi pengembangan, i. Diuleni hingga kalis dan menjadi adonan, m. Hasil campuran (adonan), n Diamkan adonan selama 20 menit dengan ditutupi oleh kain, o. Bagi adonan dengan merata, p. Adonan yang sudah siap lalu digoreng dengan api kecil hingga warnanya agak kecoklatan, q. Didinginkan dahulu, r. Kemudian kue siap untuk disaji.

\section{Analisis Gizi setelah Pengolahan}

Dari analisis yang dilakukan maka didapatkan hasil sebagaimana tersebut pada tabel berikut ini: 
Tabel 1. Kandungan Gizi Pada Kripik Dan Kue Donat Kulit Pisang

\begin{tabular}{lcc}
\hline \multicolumn{1}{c}{ Zat gizi } & Kripik & Kue Donat \\
\hline Karbihidrat & $42,5 \%$ & $52,9 \%$ \\
Protein & $1,00 \%$ & $1,32 \%$ \\
Lemak & $1,5 \%$ & $2,3 \%$ \\
Kalsium & $7,5 \%$ & $10 \%$ \\
Fosfor & $9,5 \%$ & $11,5 \%$ \\
Besi & $1,2 \%$ & $2.1 \%$ \\
Vitamin B & $0,9 \%$ & $1.5 \%$ \\
Vitamin C & $1,75 \%$ & $2.59 \%$ \\
\hline Sumber: Data Pribadi & &
\end{tabular}

Dari data tersebut diatas maka dapat dijelaskan bahwa terdapat perbedaan komposisi gizi pada kripik dan kue donat kulit pisang. Selain itu, jika penelitian ini dibandingkan dengan penelitan shah maka penelitian ini kandungan gizinya lebih tinggi. Shah (2012) dalam Haryanto (2016) bahwa limbah kulit pisang memiliki protein dan karbohidrat yang sangat tinggi (Shah et al., 2012 dalam Haryanto, dkk, 2016), karbohidrat 59.09\%, protein $0.90 \%$ dan serat 31.7\%. (Anhwange et al., 2009 dalam Haryanto, dkk, 2016). Selain itu juga limbah kulit pisang mengandung beberapa mineral, seperti natrium, kalsium, magnesium, fosfor, seng dan mangan (Emaga et al., 2006 dalam Haryanto, dkk, 2016).

\section{KESIMPULAN}

Kesimpulannya adalah Pengetahuan masyarakat desa Batu Merah meningkat tentang pengolahan limbah kulit pisang menjadi kripik dan kue. Pencemaran lingkungan akibat limbah kulit pisang yang dibuang ke sembangan tempat talah diminimalisir dengan diolahnya menjadi kripik dan kue. Masyarakat Desa Batu Merah telah memanfaatkan limbah kulit pisang sebagai sumber makanan yang berkalsium tinggi guna memenuhi kebutuhan gizi keluarga dan telah dimanfaatkan oleh masyarakat untuk memenuhi kebutuhan hidup. Sedangkan nilai gizinya setelah pengolahan lebih tinggi yaitu Zat gizi untuk Kripik karbihidrat 42,5 \%, Protein 1,00 \%, Lemak 1,5 \%, Kalsium 7,5 \%, Fosfor 9,5\%, Besi 1,2 \%. Vitamin B 0,9 \%Vitamin C 1,75\%. Sedangkan untuk donat karbohidrat $52,9 \%$, protein $1,32 \%$, lemak $2,3 \%$, kalsium $10 \%$, fosfor $11,5 \%$, Besi $2.1 \%$, Vtamin B1.5 \%,dan vitamin C2.59\%. 


\section{SARAN}

Perlu dilakukan sosialisasi lebih banyak lagi di daerah daerah lain, agar masyarakat di daerah lain dapat mengetahui manfaat limbah kulit pisang menjadi kripik dan kue agar dapat dimanfaatkan dengan baik dan bijak, sehingga limbah kulit pisang tidak di buang kesembarangan tempat lagi.

\section{DAFTAR PUSTAKA}

Anonim. 2015. Profil Kabupaten/Kota Ambon Maluku. http://ciptakarya.pu.go.id/profil/profil/timur/maluku/ambon.pdf. Diakses tanggal 25 Maret 2015

Haryanto, Aris, Miharja, Kandita, Wijayanti, Nastiti. 2016. Effects of Banana Peel Meal on the Feed Conversion Ratio and Blood Lipid Profile of Broiler Chickens. International Journal of Poultry Science 15.1:27-34

Satria, H Berry \& Ahda,Yusuf. Pengolahan Limbah Kulit Pisang Menjadi Pektin Dengan Metode Ekstraksi. Journal. Jurusan Teknik Kimia, Fak. Teknik, Universitas Diponegoro.

Suprapti LM. 2005. Keripik, Manisan Kering, dan Sirup Nangka.Yogyakarta (ID): Kanisius. 